FACTA UNIVERSITATIS

Series: Linguistics and Literature Vol. 17, $\mathrm{N}^{\mathrm{o}} 1,2019$, pp. $75-83$

https://doi.org/10.22190/FULL1901075S

Original Scientific Paper

\title{
PARTIAL TRANSPHONEMIZATION OF ENGLISH LOANWORDS IN SERBIAN: ACOUSTIC EVIDENCE FROM THREE VOWELS
}

\author{
UDC 811.111'342.1:811.163.41'342.1 \\ 811.163.41'373.45:811.111
}

\section{Nina Sudimac*, Violeta Stojičić}

University of Niš, Faculty of Philosophy, Serbia

\begin{abstract}
Following the principles of lexical borrowing which regulate the phonological adaptation of English loanwords in the Serbian language, we investigate the acoustics of the partial transphonemization of three English vowels. We have employed the Praat software in the acoustic analysis of speech to measure the values of the first three formants and the duration of vowels in accented positions in a sample of English loanwords integrated into Serbian in contrast to the corresponding vowels in English words. First, we contrast the acoustic features of the English vowels $/ \mathrm{N} /, \mathrm{I} /$ and $\mathrm{l} / \mathrm{/}$ and the Serbian vowels $/ \mathrm{a} / \mathrm{K} / \mathrm{i} /$ and $/ \mathrm{u} /$ by measuring the first three formants of the vowels in speech produced by English-Serbian native bilingual speakers. Second, we measure the duration of vowels in pairs of English words and their replicas in Serbian which we labelled 'false acoustic pairs' due to the differences in vowel length. The results verify the principle of substitution which governs the integration of loanwords on the phonological level in Serbian as a borrowing language, which requires that borrowed words comply with the phonological system of the language, in which case the phonological adaptation of phonemes of different qualities is partial.
\end{abstract}

Key words: loanword, phonological adaptation, transphonemization, English, Serbian

\footnotetext{
Submitted November 22, 2018; Accepted March 12, 2019

Corresponding author: Violeta Stojičić

University of Niš, Faculty of Philosophy

E-mail: violeta.stojicic@filfak.ni.ac.rs

" Prepared as a part of the project Dinamika struktura savremenog srpskog jezika (178014), financed by the Ministry of Education, Science and Technological Development of the Republic of Serbia.

${ }^{* *}$ Prepared as a part of the project Modern Trends in Researching English Linguistics and Anglophone Literature and Culture, conducted at the University of Niš - Faculty of Philosophy (No. 183/1-16-1-01), Serbia. 


\section{THEORETICAL CONSIDERATIONS}

The literature on English loanwords in Serbian has demonstrated that, in the process of borrowing, loanwords are adapted to the phonological system of Serbian, both on a segmental level, on which native phonemes are utilized to represent the sounds from the original word, and on a suprasegmental level, on which the loanwords comply with the native phonotactics, stress and tone.

In this paper we shall examine the acoustics of partial phonological adaptation of three English vowels in Serbian. Given that the phonological systems of the two languages differ considerably, there are principles by which the integration of loanwords operates in Serbian when the inventory of phonemes encounters nonnative material. Generally speaking, in phonological terms, Serbian opts for substitution rather than importation in the process of lexical borrowing. The research presented in this paper aims at providing acoustic information on the process of substitution operating in partial phonological adaptation of English vowels in Serbian.

\subsection{Studies in loanword phonology}

In loanword phonology there are two views of the lending language phonetics, described in the literature as the phonological model (cf. Paradis and LaCharite 1997; LaCharité and Paradis 2005) and the perceptual model (cf. Kenstowicz 2003; Peperkamp and Dupoux 2003; Boersma and Hamann 2009). The perceptual model views loanword adaptation as dependent upon the subphonemic phonetic information of the input structure. Peperkamp and Dupoux (2003) propose that loanword adaptations are phonetically minimal transformations which apply in perception. They base their conclusions on the evidence of a psycholinguistic type collected from aspects of nonnative phonological structure which are systematically distorted in speech perception, and claim that transformations in loanwords result from unfaithful perception, so that the transformations are essentially phonetic.

Paradis and LaCharité (1997), the advocates of the phonological model, hold that loanword adaptation should be considered phonological. They examined 12 corpora of English and French loanwords in different languages. The results of the analysis indicate that the ruling mechanism of loanword adaptation is a phonological transformation. In the phonological model it is claimed that if a lending language phonological category does not exist in the borrowing language, then this category will be replaced by the closest phonological category in the borrowing language, even if an acoustically closer alternative exists.

\subsection{Adaptation of English loanwords in Serbian}

In the literature, the phonological adaptation of English words borrowed into Serbian has rarely been addressed. Moreover, the acoustic evidence for the adaptation of loanwords has never been offered. As for the general principles of adaptation of English loanwords in Serbian, we shall refer to Filipović $(1989,1990)$ for explanations and classification. The original word borrowed is the 'model' and the integrated loanword is the 'replica'. The modifications in the process of adaptation of a borrowed English word can be classified into a) changes that take place from the moment of transfer of the model into the borrowing language up to the point the replica is integrated into its system, and 
b) changes that take place in the replica as soon as it is integrated into the system of the borrowing language. This is the basis of the distinction between primary and secondary changes. Primary changes are essentially unstable, so they produce compromise replicas. Changes in the replica in the secondary stage are rather slow and in agreement with the system of the receiving language.

In the process of phonological adaptation, substitution is a common method, due to the qualitative and quantitative differences between English and Serbian phonemes. The adaptation at the phonological level is labelled 'transphonemization'. Transphonemization can be classified into three categories, i.e. complete transphonemization, partial transphonemization and free transphonemization. Complete transphonemization involves the substitution of the phonemes of the donor language by the corresponding phonemes of the borrowing language. This is the case, for example, with consonants which are characterised by the same manner of articulation, for example the bilabial nasal consonant $/ \mathrm{m} / \mathrm{in}$ Eng. monitor and Ser. monitor. Partial transphonemization involves the substitution of a phoneme in the model by the analogous phoneme in the replica which has only some of the features present in the model phoneme. With vowels, for instance, partial transphonemization involves shifts in the place of articulation and/or narrowing or enlarging the mouth opening. The sample of corresponding English and Serbian vowels we selected for our research falls into this category, as shall be discussed below. Finally, free transphonemization is applied when the phonological systems differ considerably and there are no conditions which, in particular instances, may allow either complete or partial type of transphonemization. Free transphonemization occurs most frequently with diphthongs, which are non-existent in the Serbian language. With English models which contain the diphthongs /aI/, /os/, or /es/, complete or partial transphonemization occurs with the first element of the diphthong while the second element is freely replaced by the phoneme $/ \mathrm{j} /$, for example Eng. nylon /'narlpn/- Ser. најлон. The diphthong /aø/ is transphonemized as two phonemes /a/ and /u/, as in Eng. cowboy /'kauboi/ - Ser. каубоj.

We shall briefly describe the vowels in the phonological system of Serbian, which differs in the number of phonemes and their articulatory and acoustic features from the English language. The system of Serbian comprises 30 phonemes $^{1}$, which include an average vowel inventory of five monophthongal vowels /a, e, i, o, u/. The distinctive features in the vowels are realized through the parameters short/long and falling/rising. More precisely, the combinations of vowel length and tone in Serbian accented syllables allow for the following four pitch accents: short falling (nёсмa), short rising (во̀ $a$ ), long falling (сне̂г) and long rising (дéme). Contrary to the vowels in English, Serbian vowels are distinguished by suprasegmental structures, namely the pitch accent. By the place of articulation, Serbian vowels are categorized into front /e, i/, middle /a/ and back vowels $/ \mathrm{o}, \mathrm{u} /$. Lip rounding is present with back vowels $/ \mathrm{u}, \mathrm{o} /$.

For the convenience of observing the partial transphonemization in the sample examined, we shall contrast the features of the English vowels $/ \mathrm{N} / \mathrm{I} / \mathrm{I} /$ and $/ \mathrm{\sigma} /$ and the Serbian vowels $/ \mathrm{a} /, / \mathrm{i} / \mathrm{and} / \mathrm{u} /$ with reference to their qualities as described in Cruttenden (2014) and Miletić (1952). In the present study, we have disregarded the English vowels $/ \varepsilon /$ and $/ \mathrm{p} /$ and the analogous Serbian vowels /e/ and /o/ for the lack of a sufficient number of monosyllabic loanwords in the vocabulary of Serbian to serve as evidence of partial transphonemization. The qualities of the vowels are the following:

\footnotetext{
${ }^{1}$ Modern Serbian Cyrillic writing system is founded upon the concept "write as you read, read as you write", so
} that a Serbian Cyrillic letter simultaneously represents the corresponding phoneme. 
a) Eng. / $/$ lax open mid-central-Ser. /a/ lax open central;

b) Eng. /I/ lax centralized raised - Ser. /i/ peripheral close front;

c) Eng. / / lax centralized raised - Ser. /u/ peripheral close back.

\section{RESEARCH OBJECTIVE AND METHODOLOGY}

The objective of this research is to contrastively investigate the acoustic parameters of the vowels of a number of monosyllabic English models and the parameters in the Serbian replicas, with regard to the process of transphonemization, which, to our knowledge, have not been studied so far in this manner. All of the loanwords examined have been fully integrated in the Serbian language and have been morphologically and semantically adapted. The sample is subclassified into two sections. The first section comprises a sample of monosyllabic English models pub, lunch, cluster with the vowel $/ \mathrm{\Lambda} /$, monosyllabic English models stick, ticket, single with the vowel /I/ and monosyllabic English models pudding, full, look with the vowel / /, and the Serbian replicas with the short pitch accent on the corresponding vowels /a/ in паб, ланч, кластер, /i/ in стик, тикет,сингл and /u/ in пудинг, фул, лук.

The respondents involved in the interview were female adolescents born in Great Britain, who were raised bilingually to acquire both English and Serbian; we, therefore, consider them native bilinguals. In the first phase of the experiment, which involved the first section of the sample, we assigned the bilingual respondents the following English sentences to read so that the words should be recorded as pronounced in a sentential context at a normal speech tempo:

1) He goes to pubs and watches football.

2) We had a quick lunch.

3) These clusters were separate molecules.

4) I've been using this deodorant stick for years.

5) I bought a ticket to Bristol yesterday.

6) A single from that CD has become a hit.

7) I like having some pudding after lunch.

8) This machine has a full equipment of tools.

9) That look has become a trend.

This first phase was followed by an interval of a few days so that the interference of the English words in the pronunciation of the corresponding Serbian replicas should be avoided. In the second phase, the respondents were assigned the following Serbian sentences ${ }^{2}$ to read:

1) Он иде у паб да гледа фудбал.

2) Добили смо ланч пакете на излету.

3) Ови кластери су били посебни молекули.

4) Овај стик против знојења користим дуго.

5) Јуче сам купила тикет за лото.

6) Сингл са тог диска је већ постао хит.

7) После ручка волим да једем чоколадни пудинг.

8) Добио сам фул седмица.

9) Тај лук је постао мода.

\footnotetext{
${ }^{2}$ The content of the sentences assigned in the two languages differs in instances in which the replica has
} undergone semantic adaptation in Serbian. 
In the second phase, the words super /'su:pə/ - Ser. cỳnep, Eng. scooter /'sku:tə/ Ser. ску̀mер, Eng. speaker /'spi:kə/ - Ser. cnùкер, Eng. casting /ka:stıy/- Ser. ка̀стинг and Eng. charter /'t $\int a$ :tə/- Ser. yàpmep were pronounced individually as we intended to investigate only the phonemic length contrasts as the result of phonemic substitution in lexical borrowing from English into Serbian.

The speech produced in all phases was recorded into Praat 6.0.14. The measuring of acoustic parameters, i.e. the formants F1, F2 and F3 and the duration (in milliseconds) of vowels in accented positions was performed in Praat as well, whereby we followed the methods and procedures from Gudurić (2004) and Ladefoged (2001, 2003, 2006). The data obtained were processed in SPSS 20.0. The statistics involves the average value of duration of each vowel, the minimal value of duration, the maximum value of duration and standard deviation.

\subsection{Data analysis}

\section{Vowels / $/$ and /a/}

Table 1 below contains the data on the production of the vowel $/ \Lambda /$ in the models $(p u b$, lunch, cluster) and the vowel / $\mathrm{a} /$ in the Serbian replicas (паб, ланч, кластер). The data indicate that the frequencies for F1 are higher in the replicas than in the models. This suggests that the Serbian vowel is more open than the English vowel, which is in accordance with their qualities described in the literature. The statistical analysis has also shown that there is a considerable difference between the F1 frequencies and the languages (p.001). On the other hand, the F2 frequencies indicate that there is no statistically relevant difference between them, which is also in accordance with the articulatory descriptions of the Serbian vowel in the replicas and the English vowel in the models, as the vowels are both central.

Table 1 The frequencies of the first three formants of the vowels $/ \Lambda /$ and $/ \mathrm{a} /$

\begin{tabular}{lrrrrrrrr}
\hline FORMANTS & \multicolumn{4}{c}{ MODEL } & \multicolumn{6}{c}{ REPLICA } \\
\cline { 2 - 9 } & \multicolumn{1}{c}{ average } & \multicolumn{1}{c}{$\min$} & \multicolumn{1}{c}{$\max$} & \multicolumn{1}{l}{ SD } & average & \multicolumn{1}{c}{$\min$} & \multicolumn{1}{c}{$\max$} & \multicolumn{1}{c}{ SD } \\
\hline F1 & 674.65 & 661.65 & 690.65 & 14.73 & 818.83 & 757.84 & 878.01 & 44.94 \\
F2 & 1290.23 & 1213.23 & 1344.23 & 68.46 & 1425.14 & 1143.00 & 1726.73 & 259.26 \\
F3 & 2913.49 & 2867.16 & 2963.16 & 48.08 & 2776.76 & 2609.77 & 2935.85 & 122.02 \\
\hline
\end{tabular}

\section{Vowels /I/ and /i/}

In Table 2 below we have provided data on the average, minimum and maximum frequencies of the vowel $/ \mathrm{I} /$ in the English models (stick, ticket, single) and the Serbian vowel /i/ in the replicas (стик, тикет, сингл). By comparing the frequencies of the F1 and F2, we noted that the Serbian vowel /i/ is articulated quite distinctly from the corresponding English vowel. The respondents articulated the English vowel /I/ with higher frequencies of F1, which indicates that the tongue is in a lower position than with the Serbian vowel. The lower F1 frequency in the Serbian vowel indicates that the vowel is close and tense unlike the English vowel. The higher values of F1 are also statistically significant (p.001). Quite the contrary, the articulation of the English vowel produced 
lower values of F2; accordingly, it is more central than the Serbian vowel, which has a higher value of F2 and moves to the peripheral area of the vowel space (p. 004).

Table 2 The frequencies of the first three formants in the vowels /I/ and /i/

\begin{tabular}{|c|c|c|c|c|c|c|c|c|}
\hline \multirow[t]{2}{*}{ FORMANTS } & \multicolumn{4}{|c|}{ MODEL } & \multicolumn{4}{|c|}{ REPLICA } \\
\hline & AVERAGE & MIN. & MAX. & SD & AVERAGE & MIN. & MAX. & SD \\
\hline F1 & 488.53 & 414.60 & 556.89 & 56.76 & 395.30 & 367.94 & 436.41 & 24.39 \\
\hline F2 & 2323.56 & 2192.03 & 2476.84 & 113.42 & 2539.47 & 2381.51 & 2705.61 & 120.48 \\
\hline F3 & 3030.65 & 2862.21 & 3183.15 & 137.46 & 3065.98 & 2972.71 & 3260.03 & 109.14 \\
\hline
\end{tabular}

\section{Vowels / $/$ / and /u/}

The data for the formants examined in the articulation of the English vowel $/ \mho /$ in the models (pudding, full, look) and the Serbian vowel /u/ in the replicas (пудинг, фул, лук) are provided in Table 3 . The data suggest that the respondents make articulatory distinctions between the two vowels in the two languages. The English vowel has higher frequency values and is articulated as more central than the Serbian vowel in short pitch accents (p. 000). The values of F1 are considerably higher in the models than in the replicas, which is also a statistically significant value (p.008); this indicates the difference in the tenseness of the two vowels, the Serbian vowel being the tense counterpart. Given that the formant F2 corresponds to vowel frontness, we may conclude that the considerably lower F2 frequency of the Serbian vowel is an indicator of its backness, whereas the higher frequencies of the English vowel indicate its centralized position in the vowel space.

Table 3 The frequencies of the first three formants in the vowels $/ \mho /$ and $/ \mathrm{u} /$

\begin{tabular}{lrrrrrrrr}
\hline FORMANTS & \multicolumn{4}{c}{ MODEL } & \multicolumn{4}{c}{ REPLICA } \\
\cline { 2 - 9 } & \multicolumn{1}{c}{ average } & \multicolumn{1}{c}{ min. } & \multicolumn{1}{c}{$\max }$. & \multicolumn{1}{c}{ SD } & average & \multicolumn{1}{c}{ min. } & \multicolumn{1}{c}{ max. } & \multicolumn{1}{c}{ SD } \\
\hline F1 & 476.00 & 451.00 & 503.11 & 28.91 & 424.02 & 411.00 & 440.32 & 11.93 \\
F2 & 2064.75 & 1791.00 & 2289.73 & 262.07 & 1161.00 & 980.00 & 1307.30 & 120.36 \\
F3 & 2922.00 & 2789.01 & 3001.22 & 101.31 & 2862.43 & 2775.34 & 2999.83 & 92.44 \\
\hline
\end{tabular}

At this point we shall discuss the data on the duration of the English vowels $/ \mathrm{N} / \mathrm{I} / \mathrm{I} /$ and $/ \mho /$ in the models and the Serbian vowels /a/, /i/ and /u/in the replicas. The English vowels are short and the Serbian vowels are in accented positions with a short pitch accent. Although the conditions for both groups of vowels are quite similar with regard to their length, we wished to examine whether the phonemes would be articulated with any difference in their duration, despite their sharing the feature of shortness, so that a statistically significant difference should occur in duration as a dependent variable. The results in Table 4 indicate that the Serbian vowels are of a longer duration than the English vowels. In Serbian, the longest duration is evident in the articulation of the vowel /a/, while /i/ and /u/ are of a somewhat shorter duration. 
Table 4 Duration of vowels (in milliseconds) in accented positions in the English models and Serbian replicas

\begin{tabular}{lcccc}
\hline Vowels & Average $(\mathrm{ms})$ & Minimum $(\mathrm{ms})$ & Maximum $(\mathrm{ms})$ & SD \\
\hline Eng. / / & 89.00 & 81.21 & 111.92 & 11.99 \\
Ser. /u/ & 97.93 & 62.63 & 125.01 & 28.99 \\
Eng. /I/ & 66.43 & 52 & 82.34 & 12.98 \\
Ser. /i/ & 94.62 & 56.00 & 113.11 & 19.07 \\
Eng. / / & 81.00 & 68.00 & 98.01 & 12.56 \\
Ser. /a/ & 123.73 & 100.10 & 1519.11 & 31.20 \\
\hline
\end{tabular}

\subsection{The analysis of vowel quality in 'false acoustic friends'}

We have also performed an acoustic analysis of pairs of English models and Serbian replicas to illustrate the substitution of long vowels by the corresponding short vowels, in the following manner: Eng. /u:/ - Ser. /u/; Eng. /i:/ - Ser. /i/; Eng. /a:/ - Ser. /a/. Such pairs of models and replicas involve words from the two languages in which the length of the vowels in accented positions differ; thus, we have labeled the pairs 'false acoustic friends'. Essentially, the vowels in English models are long while the vowels in Serbian replicas are in a short pitch accent. The pairs include words such as Eng. super /'su:pə/ Ser. cỳnep, Eng. scooter /'sku:tə/ - Ser. скỳmep, Eng. speaker /'spi:kə/ - Ser. спѝкер, Eng. casting /ka:stın/ - Ser. ка̀стинг and Eng. charter /'t fa:tə/ - Ser. чàpmep.

Table 5 The duration of vowels (in milliseconds) in accented positions in 'false acoustic friends'

\begin{tabular}{lcccc}
\hline VOWELS & AVERAGE $(\mathrm{ms})$ & MINIMUM $(\mathrm{ms})$ & MAXIMUM $(\mathrm{ms})$ & SD \\
\hline Eng. /u:/ & 149.33 & 123.00 & 168.21 & 19.04 \\
Ser. /u/ & 94.66 & 62.63 & 125.00 & 32.39 \\
Eng. /i:/ & 151.83 & 118.00 & 188.13 & 25.72 \\
Ser. /i/ & 95.19 & 83.16 & 111.00 & 10.59 \\
Eng. /a:/ & 158.21 & 118.00 & 199.11 & 22.24 \\
Ser. /a/ & 106.51 & 62.63 & 159.11 & 20.78 \\
\hline
\end{tabular}

The data presented in Table 5 indicate that the vowels in English models are of a longer duration than the equivalent Serbian replicas. Quantitatively speaking, the difference in duration between the English words with the vowel /u:/ and the Serbian words with the vowel $/ \mathrm{u} /$ is $54.67 \mathrm{~ms}$; the difference in duration between the English words with the vowel /i:/ and the Serbian words with the vowel /i/ is $56.64 \mathrm{~ms}$; the difference in duration between the English words with the vowel /a:/ and the Serbian words with the vowel /a/ is $51.7 \mathrm{~ms}$. Accordingly, the English vowels are realized with a significantly longer duration. This acoustic information could indicate that in Serbian there may be a tendency to adapt polysyllabic English words in which long vowels are in the first syllable in such a manner that the long vowels are substituted by the corresponding vowel with the short rising pitch accent. We believe, however, that this assumption could be further substantiated. 


\section{CONCLUDING REMARKS}

In this paper we have examined the partial phonological adaptation of English vowels in Serbian by analyzing the speech of Serbian-English native bilingual speakers. The research involves the experimental acoustic analysis of three vowels in a sample of words which includes a selection of monosyllabic loanwords in Serbian and their English models. The analysis has focused on the adaptation of the English vowels to demonstrate the acoustic aspects of partial transphonemization in loanwords which are fully integrated in the Serbian language. The values of formants of individual vowels in English and Serbian words indicate that there are articulatory and acoustic differences in the production of the vowels, which suggests that the transphonemization is partial. For instance, in the vowels Eng. $/ N /$ and Ser. $/ \mathrm{a} /$ the openness is a category which is realized in a different manner, since the bilingual speakers interviewed pronounce the English vowel with a greater openness. Further, in quantitative terms, the vowels Eng. $/ \mho /$ and Ser. $/ \mathrm{u} / \mathrm{are}$ of the same duration, but in articulatory terms, they take up different positions in the vowel space: the English vowel is central, while the Serbian vowel shifts to the periphery. As far as the quantity of the other two pairs of vowels is concerned, the contrastive measurements of the durations of vowels $/ \mathrm{N} /$ and $/ \mathrm{a} /$ and $/ \mathrm{I} /$ and $/ \mathrm{i} /$ have demonstrated considerable differences.

\section{REFERENCES}

Boersma, Paul and Silke Hamann. 2009. "Loanword adaptation as first-language phonological perception". Loan Phonology 307: 11.

Cruttenden, Alan. 2014. Gimson's Pronunciation of English, $8^{\text {th }}$ edition. London: Routledge.

Filipović, Rudolf. 1990. Teorija jezika u kontaktu. Zagreb: Školska knjiga.

Filipović, Rudolf.1989. "Some Contributions to the Theory of Contact Linguistics", In Yugoslav General Linguistics, edited by Milorad Radovanović, 47-71. Amsterdam/Philadelphia: John Benjamins Publishing Company.

Gudurić, Snežana. 2004. O prirodi glasova. Beograd: Zavod za udžbenike i nastavna sredstva.

Kenstowicz, Michael. 2003. "The role of perception in loanword phonology". Studies in African Linguistics 32: 95-112.

LaCharité, Darlene and Carole Paradis. 2005. "Category preservation and proximity versus phonetic approximation in loanword adaptation". Language 36: 223-258.

Ladefoged, Peter. 2001. A course in Phonetics. Los Angeles: University of California.

Ladefoged, Peter. 2003. Phonetic Data Analysis: An Introduction to Fieldwork and Instrumental Techniques. Oxford: Blackwell Publishing.

Ladefoged, Peter. 2006. Vowels and Consonants: An Introduction to the Sounds of Languages. Oxford: Blackwell Publishing.

Miletić, Branko. 1952. Osnovi fonetike srpskog jezika. Beograd: Znanje.

Paradis, Carole and Darlene LaCharité. 1997. "Preservation and minimality in adaptation". Journal of Linguistics 33: 379-430.

Peperkamp, Sharon and Emmanuel Dupoux. 2003. "Reinterpreting loanword adaptations: the role of perception". Proceedings of the 15th international congress of phonetic sciences: 367-370. 


\section{DELIMIČNA TRANSFONEMIZACIJA ENGLESKIH POZAJMLJENICA U SRPSKOM: AKUSTIČKI DOKAZ IZ TRI SAMOGLASNIKA}

Na osnovu principa leksičkog pozajmljivanja koji upravljaju fonološkom adaptacijom engleskih pozajmljenica u srpskom jeziku ispitujemo akustičke parametre delimične transfonemizacije triju engleskih samoglasnika. Primenili smo program Praat u akustičkoj analizi govora kako bismo izmerili vrednosti prva tri formanta i trajanje samoglasnika u akcentovanim slogovima u okviru uzorka engleskih pozajmljenica koje su prihvaćene u srpskom u poređenju sa odgovarajućim samoglasnicima u engleskim rečima. Prvo, uporedićemo akustička svojstva engleskih samoglasnika $\mathrm{I} / \mathrm{V}, \mathrm{II} / \mathrm{i} / \mathrm{J}$ i srpskih samoglasnika/a/, /i/ $i$ /u/ tako što cemo izmeriti prva tri formanta ovih samoglasnika u govoru englesko-srpskih dvojezičnih govornika. Drugo, izmerićemo trajanje samoglasnika u parovima engleskih reči i njihovih srpskih replika koje smo opisali kao 'lažne akustičke parove' zbog razlika u trajanju samoglasnika. Rezultati potvrđuju princip supstitucije koji reguliše integraciju pozajmljenica na fonološkom nivou u srpskom jeziku kao jeziku koji pozajmljuje, koji zahteva da se pozajmljene reči uklope u fonološki sistem srpskog, što znači da je u tom slučaju adaptacija fonema drugačijih kvaliteta delimična.

Ključne reči: pozajmljenica, fonološka adaptacija, transfonemizacija, engleski, srpski 